\title{
Outlook for Food and Agriculture in 1981
}

\author{
NEIL A. STEVENS
}

$\mathbf{P}$ RODUCTION of a number of major food products in the United States is predicted to decline slightly from 1980 levels. Continued increases in demand for food, and thus faster increases in food prices, are in prospect. Also, a sizable increase in net farm income is expected. These were among the conclusions presented by U.S. Department of Agriculture (USDA) analysts at the 1981 Food and Agricultural Outlook Conference in Washington, D.C., last November and are summarized in this article.

\section{Factors Underlying the 1981 Forecasts}

Food price developments result from the interaction of demand and supply forces. The major factors affecting the demand for food include per capita real income, population growth and the general rate of inflation. In 1980 economic growth slowed or stopped in most countries. At the outlook conference, USDA analysts expected only slight economic growth in the United States during the first half of this year, with somewhat more rapid growth in the second half. More recent developments, however, suggest that economic growth in the first half of the year may be more sluggish than USDA analysts expected. Although real income growth will not be a major factor increasing the demand for food, world population growth will continue to increase and will contribute to an increase in export demand for U.S.-grown foodstuffs.

Supply factors dominated the outlook for food prices and farm income in 1981. The bulk of food output in the first half of 1981 will be derived largely from livestock production already under way and $1980 \mathrm{crop}$ production.

World production of grains, which includes wheat, rice, and feed grains, in 1980 was roughly equal to that in 1979. However, world stocks at the beginning of the year were lower so that available supplies in the 1980/81 marketing year are down about 2 percent. Among grains, however, supplies of food grains (wheat and rice) have increased relative to feed grains (corn, sorghum, oats and barley). World food grain production in $1980 / 81$ rose 3.5 percent over 1979/80; feed grain production fell about 3 percent, largely as a result of a severe U.S. drought.
Reduced feed grain supplies will affect U.S. retail food prices primarily through lower livestock production and higher prices of livestock products. Total meat output in 1981, incleding beef, veal, mutton and poultry, is expected to decline 1 to 3 percent below the record levels in 1980 . In contrast, total meat output rose about 3 percent last year.

Most of the decline in meat output will reflect reduced pork production. USDA analysts expected hog producers to reduce the June-November pig crop by about 10 percent as a result of feeding losses in the spring and summer of 1980 . Consequently, pork production in the first half of 1981 was expected to drop about 11 percent from a year earlier. Recent information, however, indicates that the June-November pig crop is down only 5 percent from the year before; as a result, pork supplies may decline only 6 percent in the first half of 1981. Production in the second half is more uncertain, but pork supplies are anticipated to be 5 to 10 percent below levels of a year earlier.

In contrast, production of beef, broilers and turkeys is expected to increase somewhat. Beef supplies will be relatively large in the first quarter of 1981 due to increased placements in feedlots during last summer's drought. However, production in the second quarter is expected to fall below that of a year earlier. Broiler output in the first half of 1981 is projected to be up slightly from 1980. Expansion in the second half of the year may increase output by 3 percent above the 1980 level. Turkey production, given relatively high prices, may increase about 6 percent. Egg output in 1981 is expected to be about 1 percent less than in 1980. Most of this decline is anticipated in the first quarter; production in the rest of the year will be about the same as last year. Milk output, on the other hand, is expected to rise 1 to 3 percent.

Crop-related food supplies, as a whole, are expected to expand slightly in 1981. The supply of cereal crops provides a substantial base for the production of cereal and bakery goods. However, the prices of some ingredients - in particular, oils and sugar - are predicted to rise. Reduced production of 


\begin{tabular}{|c|c|c|c|c|}
\hline Food category & 1978 & 1979 & 1980 & 19811 \\
\hline All food & $10.0 \%$ & $10.9 \%$ & $8.7 \%$ & $12.2 \%$ \\
\hline Food away from home & 9.0 & 11.2 & 10.0 & 10.4 \\
\hline Food at home & 10.5 & 10.8 & 8.1 & 13.0 \\
\hline Meats & 18.7 & 17.0 & 3.5 & 17.9 \\
\hline Beef and veal & 22.9 & 27.3 & 6.4 & 13.5 \\
\hline Pork & 12.9 & 1.5 & -2.6 & 27.6 \\
\hline Other meats & 17,8 & 14.7 & 4.1 & 17.5 \\
\hline Poultry & 10.3 & 5.0 & 4.1 & 18.0 \\
\hline Fish and seatood & 9.5 & 9.8 & 9.2 & 9.6 \\
\hline Eggs & -5.5 & 9.5 & -3.1 & 16.9 \\
\hline Dairy products & 6.7 & 11.6 & 10.2 & 10.7 \\
\hline Fats and olls & 9.5 & 80 & 6.7 & 11.0 \\
\hline Futs and vegetables & 11.1 & 8.0 & 7.0 & 8.0 \\
\hline Sugar and sweets & 12.2 & 7.8 & 22.4 & 21.5 \\
\hline $\begin{array}{l}\text { Cereals and bakery } \\
\text { products }\end{array}$ & 8.9 & 101 & 11.9 & 10.9 \\
\hline Vonalcoholio beverages & 5.7 & 5.0 & 10.8 & 12.0 \\
\hline Other prepared toods & 8.0 & 10.1 & 10.9 & 10.3 \\
\hline
\end{tabular}

IUSDA forecast

SOURCE, Paul C Westcott, "1981 Food Price Outlook" (Presented at the 1981 Agriculture Outlook Conference, Washington, $\mathrm{D} . \mathrm{C}$., November 19 . 1980), D. 10 .

oilseeds will cause the prices of fats and oils to rise by $I 1$ percent. World sugar production in $1980 / 81$ is slightly above the reduced 1979/80 crop, but beginning stocks are estimated to be down for the second consecutive year. Raw sugar prices in late 1980 were up 67 percent from the 1979 average. At the retail level, the price of sugar and other sweeteners advanced 22 percent in 1980; a similar advance is expected in 1981. A significant development in the sweetener market is the sharp increase in the use of corn-derived sweeteners. These have grown from about 16 percent of the market in 1970 to about 33 percent in 1980 and may reach nearly 50 percent of the market for nutritive sweeteners by 1985.

Supplies of fruits, including fresh apples and most canned and frozen fruits, are greater than a year ago. Until the January freeze in Florida, a record citrus crop was expected. That crop has now been reduced significantly by the freeze. Florida orange production, which accounts for aloout 75 percent of the total orange crop, is expected to be down about 20 percent. Large stocks of frozen orange juice, however, will tend to moderate the price impact of the freeze.

Supplies of processed vegetables, both canned and frozen, are down about 6 percent in 1980/81, reflecting a plamed cutback in production. The fall 1980 potato crop is down about 12 percent, and the fresh winter vegetable crop was reduced by the recent freeze in Florida. Hence, supplies of some fresh vegetables will be reduced until replanted crops come to market.

\section{Food Price Increases - Higher than General Inlation}

Given these demand and supply developments, food prices on a yearly average basis are projected to rise about 12.5 percent from 1980 to 1981 . This increase is expected to be somewhat greater than the anticipated rate of inflation as measured by the consumer price index (CPI). In contrast, food prices in 1980 rose 8.7 percent, while the CPI increased 13 percent.

Developments in the first half of 1980, however, were quite different compared to the second half of the year. In the first six months, farm prices were below the previous year, reflecting large grain supplies from the 1979 harvest and record meat output. Farm prices began to rise sharply in the second half of 1980 as increases in livestock production slowed and as the effects of the summer drought on crop production led to higher grain prices. As a result, retail food prices rose substantially in the second half of the year.

The projected year-to-year price changes for various food groups in 1981 are shown in table 1. Meats, poultry, eggs and sugar are the main food groups with the greatest projected price increases in 1981. Large increases for these groups reflected the expected decline in overall meat output. This decline and, hence, the upward pressure on the prices of animal protein foods may not be as great as USDA analysts expected, since indications are that pork production will not decline as much as anticipated. On the other hand, the increase in fruit and vegetable prices is now likely to be greater than projected due to the freeze damage in Florida.

\section{Fam Income to Recover Much of Last Year's Decline}

Price increases of meats and other livestock products are expected to lead to a recovery of farm income 
Table 2

\section{Farm Income (billions of dollars)}

\begin{tabular}{|c|c|c|c|c|}
\hline & 1978 & 1979 & 19801 & 19811 \\
\hline Gash receipts & $\$ 112.5$ & $\$ 131.5$ & $\$ 140$ & $\$ 158$ \\
\hline Gop & 53.5 & 62.8 & 71 & 77 \\
\hline Livestock & 59.0 & 68.6 & 69 & 81 \\
\hline Other income & 14.0 & 14.0 & 16 & 17 \\
\hline Total farm income & 126.5 & 145.5 & 156 & 175 \\
\hline Production expenses & 100.8 & 118.6 & 131 & 147 \\
\hline Net cash income & 33.8 & 35.8 & 34 & - \\
\hline $\begin{array}{l}\text { Net farm income } \\
\text { (betore inventory } \\
\text { adustment) }\end{array}$ & 25.7 & 26.9 & 25 & 28 \\
\hline $\begin{array}{l}\text { Net farm income } \\
\text { (after inventory } \\
\text { adjusiment) }\end{array}$ & 26.1 & 31.0 & $\begin{array}{c}24 \\
(23-25)\end{array}$ & $\begin{array}{c}29.5 \\
(27-32)\end{array}$ \\
\hline
\end{tabular}

IUSDA forecast

SOURCE George H. Hoftnan, "Farm Incone Situation and Outlook" ("Fresented at the 1981 Agriculture Outlook Conference, Washington, D.C., November 19,1980 ), pp. $6-10$

from the relatively low 1980 level. Overall, net farm income of farm operators is forecast at about $\$ 30$ billion, up 20 percent from 1980, and only slightly below the 1979 level (table 2).

For the year 1980 as a whole, prices received by farmers were only 2 percent above 1979 , and total cash receipts were up 6.5 percent. Total farm income including cash receipts, other cash income, government payments and imputed income on such items as family dwellings, was up about 7 percent. Production expenses, reflecting general inflation trends in the economy, rose over 11 percent in 1980 . Increases in input prices were led by a 39 percent increase in fuel and energy, a 23 percent rise in fertilizer and a 20 percent gain in short-term interest rates.

As a result of the faster rise in farm input prices over farm commodity prices, 1980 net farm income after inventory adjustment was about $\$ 24$ billion, down $\$ 7$ billion from 1979. Cash flow, a measure of the farmer's ability to meet short-run obligations which excludes imputed income and expenses, did not decline so sharply. This measure totaled around $\$ 34$ billion, down 5 percent from 1979. Much of the difference between net farm income and cash flow was due to a reduction in inventories.
In general, crop producers in 1980 fared better than livestock producers. Crop receipts went up 13 percent, while livestock cash receipts remained unchanged. However, there were considerable income differences among crop farmers. In some areas, drought reduced crop yields significantly and incomes were down sharply. Good yields and significantly higher prices resulted in improved incomes in the upper Midwest and eastern Corn Belt. Among livestock producers, hog operators fared relatively poorly. Dairy farmers, reflecting increased government price supports, had generally profitable operations.

The projected increase in farm income in 1981 is based largely on a 16 to 20 percent increase in livestock receipts. Crop receipts are expected to increase by 6 to 10 percent.

Production expenses are expected to increase by 11.5 percent, about the same rate as in 1980 . Farm origin input costs, unlike last year, are expected to rise sharply. Total feed expenses will rise by 15 percent or more to ration the reduced supply among competing uses. Expenses for purchased livestock are expected to rise about 10 percent. Petroleum-based inputs such as fuel, fertilizer and chemicals may register significant gains. With a slower rate of overall inflation expected, a moderation of price increases for manufactured inputs is anticipated. Total interest expense is not anticipated to rise significantly, even though farm debt will be larger. Short-term interest rates are expected to fall from 1980 levels.

\section{OUTLOOK FOR MAIOR FARM PRODUCTS}

\section{Teed Grains}

U.S. production of feed grains in 1980 was about 198.3 million tons, 17 percent below the record harvest in 1979. Planted acreage was 2.4 percent above 1979 , but a severe drought in some major producing areas reduced yields to 1.95 metric tons per acre, down 16 percent from 1979 's record yields. With the relatively large feed grain carryover from 1979/80, overall U.S. supplies (production plus stocks) for the 1980/81 marketing year totaled 250.5 million tons, 12 percent below 1979/80. Production of corn, the major feed grain, was 6.6 million bushels in 1980/81 compared with 7.9 million bushels in 1979/80. Supplies (production plus carryover) totaled 8.2 million bushels, down from 9.2 million bushels in $1979 / 80$.

With the quantity of feed grains essentially fixed by the 1980 harvest plus $1979 / 80$ carryover stocks, 
price changes in the next few months will result primarily from changes in demand. Demand is expected to remain strong, reflecting increased demand for exports and domestic food. Domestic livestock feeding, primarily hog feeding, however, will decline somewhat from the previous year as average feed grain prices are expected to be significantly above those for last year. Corn and sorghum prices are expected to average about $\$ 3.40$ and $\$ 3.30$ per bushel, respectively, compared with $\$ 2.50$ and $\$ 2.35$ per bushel, respectively, last year.

Total feed grain use may be only slightly below that of the $1979 / 80$ season, and carryover stocks will be substantially reduced. U.S. stocks are expected to fall from 52 million metric tons at the end of the 1979/80 marketing year to 21 million tons at the end of the current year. The ratio of stocks to utilization is expected to decline to 9.2 percent, the lowest since 1975 .

While feed grain prices are expected to be higher this year than last year, their impact on incentives to increase production will be partially offset by a sizable increase in prices paid by farmers for production items. Nevertheless, higher feed grain prices, and hence higher profits, will provide incentive for farmers to increase feed grain acreage and production inputs per acre. According to USDA projections, given normal weather conditions this year, com yields are likely to rise to about 103 bushels per planted acre, up 14 percent from last year but still below the record 109 bushels per acre in 1979 .

\section{Food Grains}

The supply of food grains, wheat and rice, is relatively more abundant than feed grains, reflecting the relatively large harvest in 1980. U.S. wheat produc tion in 1980 was a record 2.37 billion bushels, up 11 percent from a year earlier, and 1980/81 supplies totaled a record 3.3 billion bushels. On a worldwide basis, however, wheat production was smaller than anticipated, which, coupled with reduced feed grain crops, led to wheat price advances in the late summer and fall. With projected use of U.S. wheat near the production level, stocks at the end of the 1980/81 marketing year are expected to remain near last year's level of 900 million bushels. Wheat prices are expected to follow a normal pattern of seasonal strength through the remainder of $1980 / 81$ and may average $\$ 4.05$ per bushel for the year, about 25 cents per bushel above last year's price. Fall plantings of winter wheat are estimated to be up 11 percent from 1980 and, with normal yields, another large U.S. wheat crop is in prospect for 1981.

U.S. rice production in 1980 was estimated at 145 million hundredweight (cwt.), 10 percent above the year before. Yields were down from recent years, but producers planted 16 percent more acres, reflecting the relatively high profits expected from rice production. While begimning stocks were down, total U.S, rice supplies are up 4.4 percent and world rice supplies are up about 3 percent. U.S. farm prices for rice in the $1980 / 81$ season are expected to average about $\$ 11.50$ per cwt., up about 10 percent from the $1979 / 80$ average. Production costs are expected to rise substantially, however, and a reduction in rice acreage is likely in 1981.

\section{Soybeans}

Production of soybeans, which constitutes about 88 percent of U.S. oilseed production, declined 20 percent in 1980. The impact of this unexpected shortfall on prices and consumption, however, was blunted by a large inventory and an increase in oilseed production elsewhere in the world. World oilseed supplies are down only about 3 percent. World consumption is expected to continue expanding, and ending stocks will be down substantially from the $1979 / 80$ level. The year-end world stock-to-use ratio is expected to be around 9.4 percent, still above most recent years. U.S. soybean supplies, however, are relatively low, and prices in the $1980 / 81$ season may average $\$ 7.90$ per bushel, up from $\$ 6.25$ a bushel in the previous season.

While soybean prices are likely to be substantially higher than last year, the soybean/corn price ratio does not provide farmers with the incentive to shift from corn to soybean production. Thus, acreage is not expected to change much from last year's level. However, a return to normal soybean yields in 1981 would result in a sharp recovery in U.S. soybean production.

\section{Cotton}

U.S. cotton production of 11.1 million bales in 1980 was down 24 percent from the relatively large 1979/ 80 crop. World production was also down, largely a result of the decline in the U.S. crop. With demand for cotton relatively strong, prices in late 1980 averaged 34 percent above the previous October.

Despite relatively low supplies and high prices, cotton acreage may decline by a half million acres or more in 1981. Prices of soybeans and grain sorghum 
have increased relative to cotton, providing an incentive to shift acres from cotton to these crops. In addition, the costs of producing cotton, in absolute terms, have increased more than some competing crops. As suming normal yields of about 1 bale per acre, supplies of cotton are expected to remain tight throughout 1981 and into 1982.

\section{Tobacco}

U.S. tobacco production in 1980 recovered from the relatively small crop in 1979 , but because of the hot and dry growing conditions, the quality of some tobacco is low. Tobacco production rose 17 percent from the very small 1979 crop as a result of a 12 percent increase in acreage and a 4 percent rise in yields. With much lower carryover stocks, however, total supplies for the 1980/81 marketing year are down about 2 percent. Tobacco production is heavily influenced by government price supports and marketing quotas, and the current law mandates a 12 percent rise in price supports for eligible tobacco.

\section{Beef Cattle}

The liquidation phase of the cattle cycle ended in 1980. The number of cattle and calves on farms as of July 1,1980 , indicated a rapid rebuilding, with cattle numbers up 4 percent from 1979 . The 1980 calf crop of 45.5 million head was up 6 percent from 1979 . Several factors, however, may increase costs of production, thereby limiting future beef herd expansion. These include a substantial increase in land converted from pasture into cropland, and higher energy costs, which limit fertilization of pastures.

Higher cattle prices are in prospect for 1981, particularly in the second quarter, as total meat supplies are expected to fall below levels of a year ago. Cattle feedlot operators increased placements during the summer as drought led to larger marketings of feeder cattle. These cattle will come onto the slaughter market in the first quarter and will moderate increases in prices. Choice steer prices are expected to average around $\$ 73$ per cwt. in the first quarter.

Although cattle marketings for slaughter will rise somewhat in the second quarter, the slaughter of nonfed beef should fall below the 1980 level if grazing conditions return to normal. As a result, overall beef production will likely fall and the price of choice steers will rise. Despite increased feeding costs, profit margins are expected to increase in the second quarm ter. However, cattle prices are not expected to increase much further in the second half of the year, and feeding margins may be reduced or even become negative. The profitability of feeding operations in the second half will depend on feed costs and therefore on the outlook for 1981 grain crops.

\section{Hogs}

Hog producers experienced large losses in the first half of 1980 as large meat supplies led to prices below $\$ 30$ per cwt. in April and May. Producers reacted by slaughtering more breeding stock and cutting back on breeding inventory. At the outlook conference, the June-November pig crop was anticipated to decline about 10 percent; more recent information, however, indicates about a 5 percent decline.

Lower production in the first half of 1981 will result in higher hog prices and upward price pressure on all animal products. With a 10 percent decline in pork production, hog prices had been expected to average around $\$ 50$ per cwt. in the first half of 1981, nearly $\$ 16$ above the depressed levels of 1980 . But with pork production likely to fall only about 6 percent in the first half, prices are not likely to reach profitable levels. This would indicate more cutbacks in pork production in the second half of 1981 .

\section{Poultry and Eggs}

After suffering losses in the first half of 1980 , broiler producers planned to reduce production in the second half of 1980. This, coupled with an unusually hot summer that caused a substantial unplanned reduction, resulted in higher prices.

Reduced breeding flocks, the result of last summer's hot weather, and higher production costs are expected to limit production increases to around 3 percent above 1980. As meat supplies decline, broiler prices are expected to rise in 1981. Wholesale prices may average around 52 cents per pound in the first quarter, increasing to around 55 cents in the second quarter and 56 cents in the second half.

Since turkey production has generally been profitable since 1977 , producers have sharply increased output. Increasing year-round consumption of turkeys has meant a substantial increase in demand. Despite higher feed costs, producers have increased the number of poults hatched for slaughter purposes in recent months, and output may increase around 7 percent to 8 percent in the first half of 1981 . Prices may average 67 cents to 70 cents per pound in the first half of 1981, compared with 57 cents in the first half of last year. 
Egg production was not profitable in 1980 . During the first half of the year, prices were low due to a weak economy and large supplies of competing pro. tein foods. In the second half, rising costs largely offset price increases. As a result, producers have cut back egg production and output is expected to be down about 1 percent from 1980. Most of the reduction will occur in the first quarter, which should canse egg prices to rise in the first half of the year.

\section{Milk}

Milk production has expanded since 1979 as favor. able prices to producers have prevailed, largely due to government price supports. Production last year was about 3 percent larger than in 1979. Milk prices are expected to rise this year, but higher feed prices will reduce producers' profits to levels below those of the past couple of years. While larger dairy herds should result in higher milk production, higher feed costs will slow total output per cow, so that production will likely rise by about 2 percent.

The government support price of manufacturing milk for the marketing year beginning October 1 was set at the minimum required level of 80 percent of parity $-\$ 12,80$ per cwt. This will be adjusted again on April 1 to reflect changes in the index of prices paid by all farmers. In price support operations, government purchases of milk in the first nine months of 1980 totaled 7.35 billion pounds, almost 8 percent of all milk marketed, compared with 1.31 billion pounds in 1979. Commercial use of milk and dairy products was down 1.6 percent in 1980, but an increase may occur in 1981. Despite this increase, USDA purchases of dairy products in price support operations are expected to continue if the gains in milk production occur.

\section{CONCLUSION}

Retail food prices in 1981 are expected to increase 12.5 percent (range from 10 to 15 percent). General inflation underlies much of the increase, though food prices may rise somewhat faster than overall prices. This reflects such adverse supply factors as reduced feed grain supplies resulting from last summer's drought, reactions of hog producers to unfavorable profit opportunities and reduced sugar supplies. As a result, substantially higher livestock and sugar prices will contribute to higher retail food prices and substantially higher net profits of farm operators. 